\title{
Influence of Concentrate in the Diet on the Metabolic, Biochemical, and Endocrine Profile of Buffalo Heifers
}

\author{
Caio Alves da Costa1, Rafael Artur da Silva Júnior'1, Bruna Higino de Souza Silva1, \\ Rebeka Pontes Menezes ${ }^{1}$, Ayna Arramis Apolinário Da Silva ${ }^{1}$, Felipe Rosendo Correia ${ }^{1}$, \\ Emanuel Felipe de Oliveira Filho', Ricardo Alexandre Silva Pessoa ${ }^{2}$, \\ Cláudio Coutinho Bartolomeu ${ }^{1}$, Pierre Castro Soares ${ }^{1 *}$
}

\footnotetext{
${ }^{1}$ Department of Veterinary Medicine, Federal Rural university of Pernambuco, Recife, Brazil

${ }^{2}$ Department of Animal Science, Federal Rural university of Pernambuco, Recife, Brazil

Email: *pcastro.pe@gmail.com
}

How to cite this paper: da Costa, C.A., da Silva Júnior, R.A., de Souza Silva, B.H., Menezes, R.P., da Silva, A.A.A., Correia, F.R., de Oliveira Filho, E.F., Pessoa, R.A.S., Bartolomeu, C.C. and Soares, P.C. (2019) Influence of Concentrate in the Diet on the Metabolic, Biochemical, and Endocrine Profile of Buffalo Heifers. Open Journal of Veterinary Medicine, 9, 79-90. https://doi.org/10.4236/ojvm.2019.97007

Received: May 22, 2019

Accepted: July 13, 2019

Published: July 16, 2019

Copyright $\odot 2019$ by author(s) and Scientific Research Publishing Inc. This work is licensed under the Creative Commons Attribution International License (CC BY 4.0).

http://creativecommons.org/licenses/by/4.0/

\section{cc) (7) Open Access}

\begin{abstract}
The objective of this study was to evaluate the profile of the main serum biochemical variables in buffalo heifers receiving diets with different concentrations of concentrate. Twenty buffalo heifers of the Murrah breed, aged six to eight months, were randomly assigned to four groups, with five replicates each, to be adapted to levels of $20 \%, 40 \%, 60 \%$, and $80 \%$ of concentrate in the diet, composed of sugarcane (bulk) and concentrated feed based on wheat, corn, and soybean meal. The experimental diets were constituted in the proportion "bulk: concentrate", based on dry matter, of " $80: 20$ " (Treatment 1), “60:40" (Treatment 2), “40:60" (Treatment 3), and "20:80" (Treatment 4). Biomarkers were evaluated for energy, protein, mineral, and endocrine profiles, as well as enzymatic activity. A positive linear effect was observed for Final Body Weight. In the energy profile, there was a positive linear effect for total cholesterol and HDL cholesterol and a quadratic effect for plasma glucose. In the protein profile, a quadratic effect was observed for the urea: creatinine ratio and a positive linear effect for total protein and albumin. For the enzymatic activity, only the variable gamma-glutamyltransferase presented a quadratic effect. In the mineral profile, a quadratic effect was observed for calcium levels and a positive linear effect for phosphorus levels and negative for chlorine levels. In the endocrine profile, no statistical differences were observed. Diet with until $80 \%$ of concentrate does not negatively influence biochemical parameters that represent the profile of energy, protein, mineral and thyroid hormones for growing buffalo heifers and favors the performance of the animals.
\end{abstract}




\section{Keywords}

Animal Nutrition, Clinical Pathology, Bubalus Bubalis, Energy Profile

\section{Introduction}

Metabolic or production diseases can be caused by imbalances in the animal organism, metabolism, and nutrient egress (glycides, proteins, minerals, and water) in feces, urine, milk, and fetuses. The majority of these diseases or nutritional and metabolic disorders are difficult to detect and limit the production of the animals, causing economic losses in livestock [1].

The buffalo species is a species with its own characteristics, and the buffalo is a species with its own characteristics, and should be treated as such, without overlapping it with management methods developed specifically for the bovine species. When one understands and respects the needs of the species, one can observe animals of easy handling, docile, with good economic return, and high longevity of production and reproduction [2].

However, studies on metabolism in the buffalo species are mostly restricted to specific physiological phases of production, such as the transitional period and early lactation. Care during the growth phase is very important to ensure the longevity of the animals in the productive system, especially with regard to highly intensified management, with diets that guarantee high energy levels in buffalo feed. Based on this premise, the objective of this study was to evaluate the profile of the main biochemical variables related to energy, protein, minerals, and enzymatic and hormonal activity in buffalo heifers receiving diets with different concentrations of concentrate.

\section{Material and Methods}

The experiment was conducted in the Buffalo farming Sector of the Animal Science Department of the Federal Rural University of Pernambuco (DZ-UFRPE), located in the municipality of Recife, Pernambuco, under the geographic coordinates $8^{\circ} 04^{\prime} 03^{\prime} \mathrm{S}$ and $34^{\circ} 55^{\prime} 00^{\prime \prime} \mathrm{W}$, from September to December 2017. This study received a favorable opinion from the Ethics Committee for the Use of Animals (CEUA) of the Federal Rural University of Pernambuco under license number 062/2018 CEUA/UFRPE.

Twenty buffalo heifers of the Murrah breed were used, aged six to eight months at the beginning of the experiment, and with an initial mean body weight of $115.51 \mathrm{~kg}$. The animals were confined in individual stalls, with dimensions of $2.0 \mathrm{~m} \times 0.8 \mathrm{~m}\left(1.6 \mathrm{~m}^{2}\right)$, with a masonry floor and covered with ceramic tiles. The animals had access to individual feed and water troughs.

The animals were randomly assigned to four groups, with five replicates each, to be adapted to levels of $20 \%, 40 \%, 60 \%$, and $80 \%$ of concentrate in the diet, composed of sugarcane (bulk) and concentrated feed based on wheat, corn, and 
soybean meal. The experimental diets were constituted in the proportion "bulk: concentrate”, based on dry matter, of “80:20” (Group 1), “60:40” (Group 2), “40:60” (Group 3), and “20:80” (Group 4).

The diets were formulated based on nutritional requirements for buffaloes (Paul, 2011), estimating a daily weight gain of between 0.500 and $0.800 \mathrm{~kg}$. The proportions of the concentrated ingredients (corn meal, wheat bran, and soybean meal) in the diets with sugarcane were adjusted according to the need to complement the proposed levels of crude protein (CP) and total digestible nutrients (TDN) to formulate isoproteic diets (Table 1).

The diets were provided as a complete mixture in individual feeding troughs twice daily at 08:00 and 16:00. To estimate the voluntary consumption, the leftovers were collected and weighed before each feeding; the consumption was measured as the difference between the feed supplied and leftover of each animal. The amount of feed provided was adjusted based on the voluntary intake of the animal, with estimated daily leftovers of between $5 \%$ and $10 \%$. Samples of the diets supplied and daily leftovers, per animal and treatment, as well as the foods used to formulate the diets, were collected weekly for further analysis of bromatological control.

The animals were weighed at the beginning and end of the experimental period to obtain the initial body weight (IBW) and final body weight (FBW) for the evaluation of total weight gain (TWG) and mean daily gain (MDG). The TWG

Table 1. Percentage composition of the ingredients and chemical composition of the experimental diets.

\begin{tabular}{|c|c|c|c|c|}
\hline \multirow{2}{*}{ Ingredients $\left(\mathrm{g} \cdot \mathrm{kg}^{-1}\right)$} & \multicolumn{4}{|c|}{ Levels of concentrate in diets with sugarcane (\%) } \\
\hline & 20 & 40 & 60 & 80 \\
\hline Wheat bran & 0.283 & 0.378 & 0.410 & 0.426 \\
\hline Corn meal & 0.147 & 0.107 & 0.092 & 0.084 \\
\hline Soybean meal & 0.283 & 0.378 & 0.410 & 0.426 \\
\hline Mineral complex & 0.126 & 0.070 & 0.057 & 0.052 \\
\hline Urea & 0.161 & 0.067 & 0.031 & 0.012 \\
\hline \multicolumn{5}{|l|}{ Chemical composition ( $\left.\mathrm{g} \cdot \mathrm{kg}^{-1} \mathrm{MS}\right)$} \\
\hline Dry matter $\left(\mathrm{g} \cdot \mathrm{kg}^{-1} \mathrm{MN}\right)$ & 478.03 & 581.86 & 686.25 & 790.86 \\
\hline Organic matter & 939.33 & 934.42 & 924.76 & 913.20 \\
\hline Crude protein & 157.83 & 157.81 & 157.13 & 156.19 \\
\hline Ethereal Extract & 15.49 & 20.13 & 24.58 & 28.95 \\
\hline Total Carbohydrates & 766.01 & 756.48 & 743.05 & 728.06 \\
\hline Neutral Detergent Fiber & 458.22 & 411.60 & 363.52 & 314.86 \\
\hline $\mathrm{NDFi}^{*}$ & 167.17 & 132.79 & 98.25 & 63.65 \\
\hline Non-Fibrous Carbohydrates & 307.79 & 344.88 & 379.53 & 413.20 \\
\hline Total Digestible Nutrients ${ }^{1}$ & 589.94 & 631.08 & 668.35 & 704.07 \\
\hline
\end{tabular}

${ }^{\star}$ Indigestible Neutral Detergent Fiber. ${ }^{1}$ Values estimated according to Valadares Filho et al. (2006). 
was obtained by the difference between the final body weight and the initial body weight $[$ TWG $=($ FBW - IBW $)]$. The MDG estimate was obtained by the relation between the TWG and the total number of days in the experimental pe$\operatorname{riod}[\mathrm{MDG}=(\mathrm{TWG} / 84)]$.

To evaluate the metabolic and endocrine profiles, blood samples were collected during the experimental period, at four moments, every 21 days. The samples were collected by jugular venipuncture, with the animals at rest, in vacutainer siliconized tubes, without anticoagulants and with sodium fluoride and ethylenediaminetetraacetic acid (EDTA), to obtain serum and plasma, respectively.

The blood samples without anticoagulant were maintained at room temperature, while those with anticoagulant were homogenized, kept under refrigeration, and taken to the laboratory for further processing. All tubes were centrifuged for 15 minutes at $500 \mathrm{G}$. Subsequently, the serum and plasma aliquots were packed in Eppendorf tubes and stored at $-20^{\circ} \mathrm{C}$ for further laboratory analysis of the biochemical and hormonal indicators.

Biochemical analyses were performed at the Laboratory of Nutritional and Metabolic Diseases at the Center for Advanced Research in Goats, located in the Department of Veterinary Medicine of the Federal Rural University of Pernambuco. The biochemical blood determinations were performed in a LABMAX 240 automated biochemical analyzer (LABTEST) using a commercial LABTEST kit.

The hormonal analyzes were carried out at the Laboratory of Analytical Chemistry of the Research Support Center (CENAPESQ) of the Federal Rural University of Pernambuco (CAPES/UFRPE Pro-Equipment Notice). To evaluate the endocrine profile, total thyroid hormones T3 (triiodothyronine) and T4 (thyroxine) were determined through the electrochemiluminescence method (ECLIA) using commercial kits in automated analytical equipment, BECKMAN COUNTER-ACCESS $2^{\circ}$. All hormonal determinations were performed in duplicate, to obtain the mean related to the animal and the respective collection.

The experimental model used was completely randomized with four groups and five replicates per groups, according to the model: $Y_{i j k}=\mu+T_{i}+e_{i j}$; where $Y_{i j}=$ dependent variable observed; $\mu=$ overall mean; $T_{i}=$ effect of groups $i(i=1$ to 4$)$; and $e_{i j}=$ experimental error. Data were submitted to analysis of variance and regression using the GLM procedure of SAS - Statistical Analysis System [3], considering a level of significance of $5 \%$ for data analysis.

\section{Results}

A positive linear effect $(\mathrm{P}<0.0001)$ was observed for Final Body Weight, and consequently for Total Weight Gain and Mean Daily Gain, with the increase in energy level in the diet given to the animals. In relation to the energy profile, a positive linear effect was found for the levels of total cholesterol $(P=0.0008)$ and HDL Cholesterol $(\mathrm{P}=0.0002)$, as the level of concentrate in the diet increased, and a quadratic effect $(\mathrm{P}=0.0089)$ for plasma glucose. However, for the other 
variables of the energy profile, there were no statistical effects $(\mathrm{P}>0.05)$ of the different levels of energy in the diet (Table 2 and Figure 1).

With respect to the protein profile, the results of the regression analysis showed a quadratic effect $(\mathrm{P}=0.0466)$ for the ratio urea: creatinine $(\mathrm{Ur}: \mathrm{Cr})$ and a positive linear effect for total protein $(P=0.0178)$ and albumin $(P=0.0136)$, according to the level of inclusion of concentrate in the diet. For the other variables, there were no statistical effects $(\mathrm{P}>0.05)$. There were no significant differences $(\mathrm{P}>0.05)$ between the treatments in relation to the biomarkers evaluated for enzymatic activity, except for gamma-glutamyltransferase, which presented a quadratic effect $(P=0.0117)$ for the concentrate increment in the diet (Table 3).

A quadratic effect was observed for the levels of total calcium $(P=0.0479)$ and ionic calcium $(\mathrm{P}=0.0374)$, and a positive linear effect for phosphorus $(\mathrm{P}=$ $0.0079)$ and negative for chlorine $(P=0.0054)$, with the increase of concentrate in the diet supplied to the animals. For the other variables analyzed, there were no statistical effects $(P>0.05)$. It can also be observed that according to data analyzed in relation to the endocrine profile, no statistical differences were observed $(\mathrm{P}>0.05)$ for the measured hormonal levels of $\mathrm{T} 3$ (triiodothyronine) and T4 (thyroxine) (Table 4).

Table 2. Mean values of performance and energy profile as a function of dietary concentrate levels of buffalo heifers.

\begin{tabular}{|c|c|c|c|c|c|c|}
\hline \multirow{2}{*}{ Variables } & \multicolumn{4}{|c|}{ Levels of concentrate in the diet (\%) } & \multicolumn{2}{|c|}{$\mathbf{P}>\mathrm{F}$} \\
\hline & 20 & 40 & 60 & 80 & $\mathrm{~L}^{1}$ & $\mathrm{Q}^{2}$ \\
\hline \multicolumn{7}{|c|}{ Performance (kg) } \\
\hline Initial Body Weight & 113.92 & 117.20 & 117.10 & 113.84 & ns & ns \\
\hline Final Body Weight & 151.70 & 175.54 & 190.84 & 212.78 & $<.0001$ & ns \\
\hline Total Weight Gain & 37.78 & 58.34 & 73.74 & 98.94 & $<.0001$ & ns \\
\hline Mean Daily Gain & 0.450 & 0.694 & 0.878 & 1.178 & $<.0001$ & ns \\
\hline \multicolumn{7}{|c|}{ Energy Profile } \\
\hline Plasma glucose $(\mathrm{mmol} / \mathrm{L})$ & 1.34 & 2.23 & 2.49 & 1.21 & ns & 0.0089 \\
\hline Lactate $(\mathrm{mmol} / \mathrm{L})$ & 7.36 & 7.35 & 8.05 & 7.40 & ns & ns \\
\hline Fructosamine $(\mu \mathrm{mol} / \mathrm{L})$ & 224.61 & 230.92 & 228.77 & 236.87 & ns & ns \\
\hline Fructosamine $_{\mathrm{PT}}(\mu \mathrm{mol} / \mathrm{L})^{3}$ & 233.78 & 230.84 & 226.66 & 221.60 & ns & ns \\
\hline Fructosamine $_{\mathrm{ALB}}(\mu \mathrm{mol} / \mathrm{L})^{4}$ & 343.14 & 323.24 & 307.46 & 305.15 & ns & ns \\
\hline Total cholesterol (mmol/L) & 1.06 & 1.46 & 1.51 & 1.68 & 0.0008 & ns \\
\hline HDL Cholesterol (mmol/L) & 0.55 & 0.80 & 0.79 & 1.04 & 0.0002 & ns \\
\hline Triglycerides (mmol/L) & 0.26 & 0.32 & 0.28 & 0.23 & ns & ns \\
\hline
\end{tabular}

${ }^{1}$ Linear; ${ }^{2}$ Quadratic; ns $=$ not significant at the $5 \%$ probability level; ${ }^{3}$ Frutosamine corrected by PT; ${ }^{4}$ Fructosamine corrected by Albumin. 
Table 3. Mean values of protein profile and enzymatic activity as a function of dietary concentrate levels of buffalo heifers.

\begin{tabular}{|c|c|c|c|c|c|c|}
\hline \multirow{2}{*}{ Variables } & \multicolumn{4}{|c|}{ Levels of concentrate in the diet (\%) } & \multicolumn{2}{|c|}{$\mathrm{P}>\mathrm{F}$} \\
\hline & 20 & 40 & 60 & 80 & $\mathrm{~L}^{1}$ & $\mathrm{Q}^{2}$ \\
\hline \multicolumn{7}{|c|}{ Protein profile } \\
\hline Urea (mmol/L) & 7.01 & 5.58 & 7.09 & 7.64 & ns & ns \\
\hline Creatinine $(\mu \mathrm{mol} / \mathrm{L})$ & 128.27 & 143.42 & 126.89 & 122.77 & ns & ns \\
\hline $\mathrm{Ur}: \mathrm{Cr}^{*}$ & 0.06 & 0.04 & 0.06 & 0.06 & ns & 0.0466 \\
\hline Total Protein $(\mathrm{g} / \mathrm{L})$ & 59.56 & 61.76 & 62.49 & 66.18 & 0.0178 & ns \\
\hline Albumin (g/L) & 21.90 & 23.54 & 24.56 & 25.56 & 0.0136 & ns \\
\hline Globulin (g/L) & 37.66 & 38.22 & 37.94 & 40.62 & ns & ns \\
\hline$A: G^{*}$ & 0.58 & 0.62 & 0.65 & 0.63 & ns & ns \\
\hline \multicolumn{7}{|c|}{ Enzymatic activity } \\
\hline Aspartate Transaminase (U/L) & 140.94 & 129.41 & 137.87 & 128.88 & ns & ns \\
\hline Gamma glutamyltransferase (U/L) & 16.68 & 23.71 & 23.48 & 16.17 & ns & 0.0117 \\
\hline Alanine aminotransferase (U/L) & 42.87 & 36.79 & 34.84 & 38.78 & ns & ns \\
\hline Alkaline Phosphatase (U/L) & 258.00 & 193.25 & 223.98 & 172.49 & ns & ns \\
\hline
\end{tabular}

${ }^{1}$ Linear; ${ }^{2}$ Quadratic; ns = not significant at the $5 \%$ probability level.
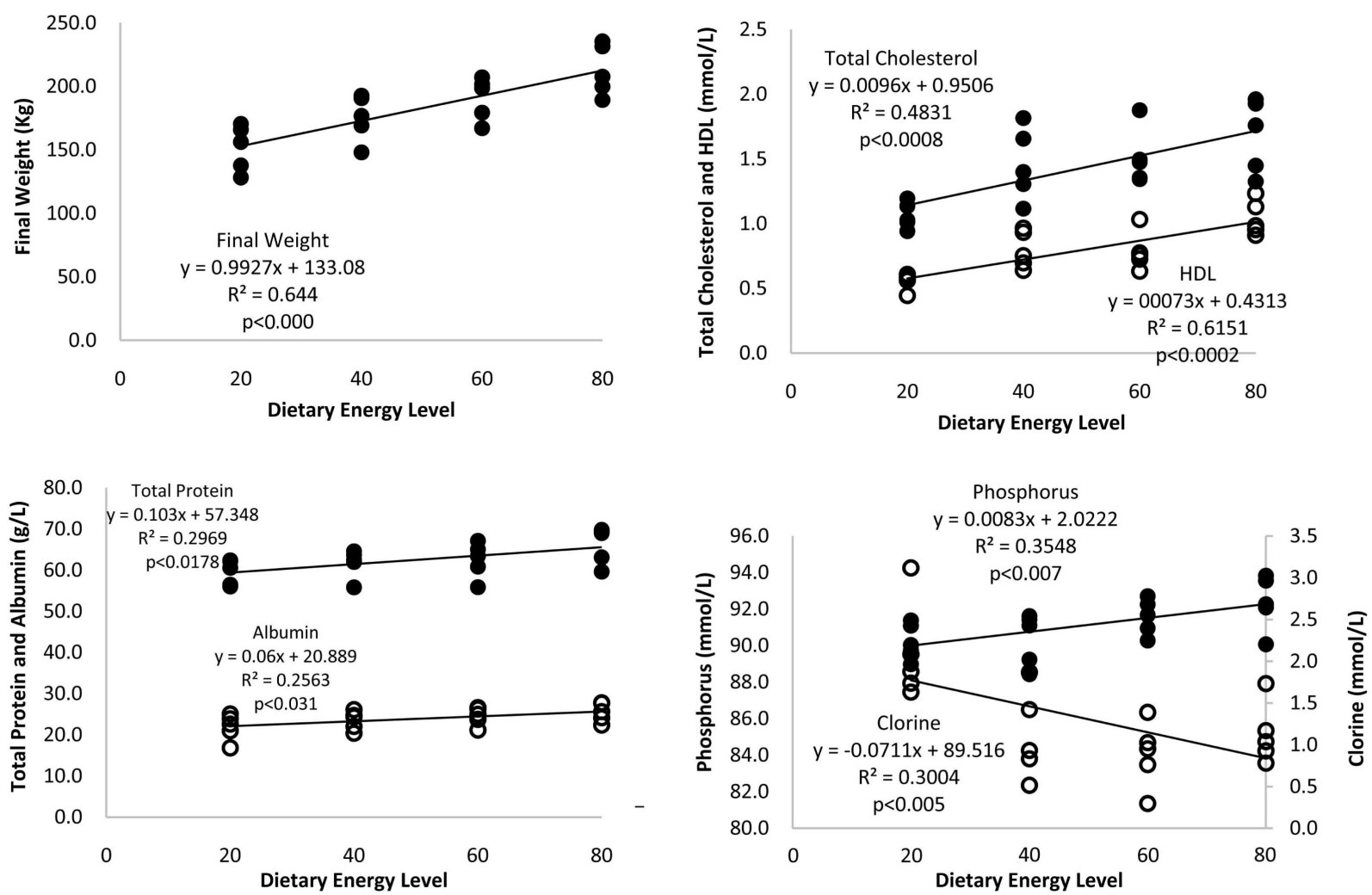

Figure 1. Graphical representation of regression analysis of final body weight and blood concentration of total cholesterol with HDL cholesterol, total protein with albumin, and phosphorus with chlorine of buffalo heifers as a function of diets with different concentrate levels. 
Table 4. Mean values of the mineral and endocrine profile as a function of dietary concentrate levels of buffalo heifers.

\begin{tabular}{|c|c|c|c|c|c|c|}
\hline \multirow{2}{*}{ Variables } & \multicolumn{4}{|c|}{ Levels of concentrate in the diet (\%) } & \multicolumn{2}{|c|}{$\mathrm{P}>\mathrm{F}$} \\
\hline & 20 & 40 & 60 & 80 & $\mathrm{~L}^{1}$ & $Q^{2}$ \\
\hline \multicolumn{7}{|c|}{ Mineral Profile } \\
\hline Total Calcium (mmol/L) & 2.35 & 1.95 & 1.96 & 2.40 & ns & 0.0479 \\
\hline Ionic Calcium (mmol/L) & 1.49 & 1.20 & 1.81 & 1.44 & ns & 0.0374 \\
\hline Phosphorus (mmol/L) & 2.24 & 2.27 & 2.53 & 2.70 & 0.0079 & ns \\
\hline Ca: $\mathrm{P}^{*}$ & 1.06 & 0.88 & 0.78 & 0.90 & ns & ns \\
\hline Magnesium (mmol/L) & 1.31 & 1.95 & 1.88 & 1.43 & ns & ns \\
\hline Sodium $(\mathrm{mmol} / \mathrm{L})$ & 141.79 & 138.80 & 137.50 & 141.45 & ns & ns \\
\hline Potassium (mmol/L) & 4.04 & 4.03 & 4.35 & 4.04 & ns & $\mathrm{ns}$ \\
\hline Chlorine (mmol/L) & 89.55 & 85.09 & 84.05 & 85.16 & 0.0054 & ns \\
\hline \multicolumn{7}{|c|}{ Endocrine Profile } \\
\hline $\mathrm{T} 3(\mathrm{nmol} / \mathrm{L})^{*}$ & 2.26 & 2.67 & 2.96 & 2.88 & ns & ns \\
\hline $\mathrm{T} 4(\mathrm{nmol} / \mathrm{L})^{*}$ & 156.58 & 157.97 & 144.99 & 155.83 & ns & ns \\
\hline
\end{tabular}

${ }^{1}$ Linear; ${ }^{2}$ Quadratic; $\mathrm{ns}=$ not significant at the $5 \%$ probability level; ${ }^{\star} \mathrm{Ca}: \mathrm{P}-$ Calcium: Phosphorus; ${ }^{\star} \mathrm{T} 3-$ triiodothyronine; ${ }^{\star} \mathrm{T} 4-$ Thyroxine.

\section{Discussion}

All the biochemical variables studied were compared with the standard of normality for cattle [4], since reference values for buffaloes were not found in the literature. From the comparison, it was possible to verify that the values were within the normal reference range, except for the variables related to the energy profile.

The final body weight values demonstrated a positive linear effect with the increase in the energy level in the diet provided to the buffaloes of the experiment, the same effect was observed for the total weight gain and mean daily gain. The same effect was observed by Franzolin et al. [5], where the buffaloes evaluated in their study presented higher daily weight gain as they were fed with increasing levels of energy in the confined diet. Campanile et al. [6] evaluated the effect of feeding with high and low concentrate diets in buffalo heifers and also observed greater weight gain and better body condition scores for the group fed a high concentrate diet.

This fact is due to the greater availability of nutrients in the diets rich in concentrate, with a greater contribution of nutrients needed both for body maintenance and development of the animals. In addition, in the groups that received diets from $40 \%$ of concentrate, the mean daily gain met the estimates of weight gain between 0.500 and $0.800 \mathrm{~kg}$, according to the diets formulated based on the nutritional requirements for buffaloes [7]. It is worth noting that even when receiving low concentrate diets (20\%), the observed value of mean daily gain was $0.450 \mathrm{~kg}$, very close to the estimates of weight gain for the category studied. 
There was a significant increase in plasma glucose levels as dietary concentrate levels increased, with a quadratic effect with inflection from the $60 \%$ level. This increase probably occurred as a function of the diet rich in non-fibrous carbohydrates used in the feed of animals supplemented with higher levels of concentrate.

The mean concentrations found in this study for total cholesterol, HDL cholesterol, and triglycerides were $1.43,0.79$, and $0.27 \mathrm{mmol} / \mathrm{L}$, respectively. In a study evaluating diets supplied with high and low concentrate for buffalo heifers, Campanile et al. [6] found values of 2.08 and $1.52 \mathrm{mmol} / \mathrm{L}$ for total cholesterol; 1.66 and $1.17 \mathrm{mmol} / \mathrm{L}$ for HDL cholesterol; and 0.19 and $0.21 \mathrm{mmol} / \mathrm{L}$ for triglycerides, respectively, in serum concentrations of animals receiving both high and low energy in their diet.

Analyzing these values, it can be seen that heifers fed a low energy diet had lower concentrations of some fundamental metabolic substrates compared to heifers fed a high concentrate diet. However, similar to the heifers studied by Campanile et al. [6], the animals in this experiment were able to maintain a relatively constant weight gain.

It is known that glucose is responsible for numerous functions in the body of ruminants and a change in the blood glucose rate could be indicative of problems in the animal's organism [8]. However, there were no significant alterations in the majority of the variables measured in the metabolic profile, or the enzymatic activity, demonstrating a metabolism within normality in the studied species.

The higher concentration of lipids in the blood is explained by fat absorbed via the intestine or from increases in lipolysis [9]. This may explain the increasing levels of total cholesterol and HDL cholesterol found with increased dietary concentrate in buffalo heifers.

The protein profile is directly related to the nutritional status of the animal, influenced by the protein input in the diet. Although the diets evaluated in this study were isoproteic (Table 1), a linear increase in total protein and albumin serum concentrations was observed. For Contreras and Phil [10] albumin is considered a more sensitive indicator to evaluate the protein status of animals, however, their responses are long term.

Nevertheless, in spite of the short experimental period, it was possible to observe increasing linear values of albumin for the buffalo heifers studied. In addition, total protein concentrations are also related to protein intake and their responses occur in the short term. Therefore, total protein concentrations also showed linearly increasing values between treatments, even with isoproteic diets. Nevertheless, the mean values of the protein variables evaluated are within the ranges found by Franzolin et al. [5] and Gomes et al. [11].

Referring to the observed results, Verdurico et al. [8] reported that the decrease in total plasma proteins is related to deficiency in the diet, after ruling out pathological causes, such as liver failure, renal and intestinal disorders, and hemorrhages, which were not observed in the experimental conditions of this 
study.

According to some studies evaluating animals of the same species, the values for the enzymatic activities of aspartate transaminase, gamma-glutamyltransferase, alanine aminotransferase, and alkaline phosphatase are within normal limits for young buffaloes [11]. However, the enzymatic activity of gamma-gluta myltransferase was influenced by the level of concentrate in the diet, presenting a quadratic effect, with the inflection of values from the inclusion of $60 \%$ of concentrate in the diet. Some authors have found an increase in gamma -glutamyltransferase activity in cattle [12] [13] and buffaloes [11].

Although this effect was observed in the gamma-glutamyltransferase activity, demonstrating greater hepatic participation in the metabolism due to the high energetic concentrations of the diet, the enzymatic profile was not influenced by the inclusion of concentrate in the diet, evidencing proper hepatic functioning, even for the buffalo heifers which received higher energy levels. This may demonstrate a better metabolic capacity of buffaloes, presenting lower rates of liver and/or muscle lesions when submitted to highly intensive nutritional management.

Regarding the mineral profile, there was an increase in calcium and phosphorus levels, but with quadratic and linear effects, respectively. The behavior of serum calcium should normally follow the linear increase of albumin presented. According to Tokarnia et al. [14], the calcium level normalizes together with the albumin, correlated with the higher intake of pasture and concentrate in the diet. However, Dias et al. [15], in a literature review, citing that excess calcium may impair reproductive function due to a secondary deficiency of phosphorus, magnesium, zinc, copper, and other microelements that may inhibit intestinal absorption.

In the current study, serum magnesium levels were found to be within the reference standards [4] and maintaining adequate concentrations of this mineral contributes to the results in relation to calcium, since bone resorption of calcium is dependent on magnesium, whose balance in concentrations is directly related to the diet provided to the animals [16]. In addition, there is a positive association between cholesterol, calcium, and magnesium [17].

Regarding the linear behavior of phosphorus, the importance of this essential mineral in the nutrition of ruminants is stressed, since it exerts important functions in the organism. According to Dias et al. [15], among the many functions of phosphorus, the most important is perhaps its participation in cellular metabolism, being part of the biochemical mechanisms linked to energy metabolism. Several components of the cell are esters of phosphoric acid, many of which are endowed with the standard free energy of hydrolysis.

Negative linear behavior of serum chlorine levels was observed as dietary energy levels increased. Sodium, chlorine, and potassium present several functions, one of which is the maintenance of osmotic pressure and acid-base balance. Even sodium and potassium play an important role in the conduction and transmission of nerve impulses, cardiac function, and transport of nutrients (so- 
dium-potassium pump). A framework of sodium and chlorine deficiency leads to perversion of appetite and reduction in milk production. Potassium is the major intracellular cation, and its functions are especially correlated to sodium and chlorine [17].

No significant differences were observed between the treatments for serum levels of thyroid hormones T3 (triiodothyronine) and T4 (thyroxine), demonstrating the hormonal metabolic homeostasis of the animals, even under diets with high levels of concentrate. This fact is evidenced by the performance values observed in the weight gain, since according to Pezzi et al. [18] and Morais et al. [19] a decrease in the hormonal metabolic rate could induce alterations in other bodily functions, such as decreased food consumption and body weight, especially in situations of intensive nutritional management.

The animals in the current study presented mean values of $2.69 \mathrm{nmol} / \mathrm{L}$ and $153.84 \mathrm{nmol} / \mathrm{L}$ for T3 and T4, respectively. Studies carried out with buffalo females of different ages and physiological conditions quantified mean values ranging from 0.37 to $3.41 \mathrm{nmol} / \mathrm{L}$ for $\mathrm{T} 3$ and from 31.28 to $73.48 \mathrm{nmol} / \mathrm{L}$ for $\mathrm{T} 4$ [20] [21].

It can be seen that the values for T3 observed in this study are similar to those found in the literature, despite differences in the age range of the animals studied. However, the values for T4 were much higher than previous works. It is probable that this increase in hormone levels is due to the increase in the metabolic rate, arising from the high levels of concentrate in the experimental diets, together with the influence of environmental factors [22] [23]. In addition, increased thyroid hormone concentrations during certain times of the year may occur due to increased food intake [24].

\section{Conclusion}

Diet with until $80 \%$ of concentrate level does not negatively influence biochemical parameters that represent the profile of energy, protein, mineral and thyroid hormones for growing buffalo heifers and favors the performance of the animals. This confirms that buffaloes have a good ability to metabolize dietary nutrients, allowing the maintenance of productive functions. In addition, this study serves as a reference parameter for serum levels of T3 (triiodothyronine) and T4 (thyroxine) in buffalo heifers (Bubalus bubalis).

\section{Conflicts of Interest}

The authors declare no conflicts of interest regarding the publication of this paper.

\section{References}

[1] Wittwer, F. (2000) Marcadores bioquímicos no controle de problemas metabólicos nutricionais em gado de leite. In: González, F.H.D. and Barcellos, J.O., Eds., Perfil metabólico em ruminantes: Seu uso e doenças nutricionais, Gráfica da Universidade Federal do Rio Grande do Sul, Porto Alegre, 53-62. 
[2] Brito, M.F. (2017) Aspectos reprodutivos e biotecnologias aplicadas à espécie bubalina. Sinapse Múltipla, 6, 60-65.

[3] SAS-Statistical Analysis System Institute (2000) User's Guide: Statistics. Version 6.12. North Carolina State University, Cary, NC.

[4] Kaneko, J.J., Harvey, J.W. and Bruss, M.L. (2008) Clinical Biochemistry of Domestic Animals. Sixth Edition, Academic Press, San Diego, CA.

[5] Franzolin, R. and Franzolin, M.H.T. (2000) População protozoários ciliados e degradabilidade ruminal em búfalos e bovinos zebuínos sob dieta à base de cana-de-açúcar. Revista Brasileira de Zootecnia, 29, 1853-1861.

https://doi.org/10.1590/S1516-35982000000600034

[6] Campanile, G., Baruselli, P.S., Vecchio, D., Prandi, A., Neglia, G., et al. (2010) Growth, Metabolic Status and Ovarian Function in Buffalo (Bubalus bubalis ) Heifers Fed a Low Energy or High Energy Diet. Animal Reproduction Science, 122, 74-81. https://doi.org/10.1016/j.anireprosci.2010.07.005

[7] Paul, S.S. (2011) Nutrient Requirements of Buffaloes. Revista Brasileira de Zootecnia, 40, 93-97.

[8] Verdurico, L.C., Gandra, J.R., Takiya, C.S., Freitas Junior, J.E., Barletta, R.V., Gardinal, R., Calomeni, G.D., Paiva, P.G. and Rennó, F.P. (2015) Differences in Blood and Milk Fatty Acid Profile of Primiparous and Multiparous Mediterranean Buffaloes Cows during Transition Period and Early Lactation. Journal of Buffalo Science, 4, 40-45. https://doi.org/10.6000/1927-520X.2015.04.02.2

[9] Jenkins, T.C. and Jenny, B.F. (1989) Effect of Hydrogenated Fat Intake, Nutrient Digestion, and Lactation Performance of Dairy Cows. Journal of Dairy Science, 72, 2316-2324. https://doi.org/10.3168/jds.S0022-0302(89)79363-2

[10] Contreras, P.A. and Phil, M. (2000) Indicadores do metabolismo proteico utilizados nos perfis metabólicos de rebanhos. In: González, H.D., Ed., Perfil metabólico em ruminantes. Seu uso em nutrição e doenças nutricionais, Centerlab, Porto Alegre, 23-30.

[11] Gomes, V., Madureira. K.M., Blagitz. M.G., Galdino. J., Vantim, G. and Benesi, F.J. (2010) Valores de referência e influência do etário sobre os parâmetros bioquímicos utilizados para avaliação da função hepática de bubalinos hígidos da raça Murrah. Ars Veterinária, 26, 128-131.

[12] Borges, A.C., Juliano, R.S., Barini, A.C., Lobo, J.R., Abreu, U.G.P., Sereno, J.R.B. and Fioravanti, M.C.S. (2011) Enzimas séricas e parâmetros bioquímicos de bovinos (Bos taurus) sadios da raça Pantaneira. Boletim de Pesquisa e Desenvolvimento, Embrapa Pantanal, Corumbá, 16.

[13] Pires Júnior, J.B., Buonora, C.R.A.R., Afonso, J.A.B., Dantas, F.R., Pereira, A.L.L., Vieira, A.C.S. and Mendonça, C.L. (2013) Transferência de imunidade passiva em bezerros. Pesquisa Veterinária Brasileira, 35, 111-116.

[14] Tokarnia, C.M.H., Peixoto, P.V., Barbosa, J.D., Brito, M.F. and Döbereiner, J. (2010) Deficiências minerais em animais de produção. Helianthus, Rio de Janeiro.

[15] Dias, J.C., Ramos, A.F., Andrade, V.J., Emerick, L.L., Martins, J.A.M. and Souza, F.A. (2010) Alguns aspectos da interação nutrição-reprodução em bovinos: Energia, proteína, minerais e vitaminas. PUBVET, 4, 738-743.

[16] Goff, J.P. (2008) The Monitoring, Prevention, and Treatment of Milk Fever and Subclinical Hypocalcemia in Dairy Cows. The Veterinary Journal, 176, 50-57. https://doi.org/10.1016/j.tvjl.2007.12.020

[17] Alvarenga, E.A., Moreira, G.H.F.A., Facury Filho, E.J., Leme, F.O.P., Coelho, S.G., 
Molina, L.R., Lima, J.A.M. and Carvalho, A.U. (2015) Avaliação do perfil metabólico de vacas da raça Holandesa durante o período de transição. Pesquisa Veterinária Brasileira, 35, 281-290. https://doi.org/10.1590/S0100-736X2015000300012

[18] Pezzi, C., Accorsi, P.A., Vigo, D., Govoni, N. and Gaiani, R. (2003) 5'-Deiodinase Activity and Circulating Thyronines in Lactating Cows. Journal of Dairy Science, 86, 152-158. https://doi.org/10.3168/jds.S0022-0302(03)73595-4

[19] Morais, D.A.E.F., Maia, A.S.C., Silva, R.G., Vasconcelos, A.M., Lima, P.O. and Guilhermino, M.M. (2008) Variação anual de hormônios tireoideanos e características termorreguladoras de vacas leiteiras em ambiente quente. Revista Brasileira de Zootecnia, 37, 538-545. https://doi.org/10.1590/S1516-35982008000300020

[20] Mayahi, S., Mamouei, M., Tabatabaei, S. and Mirzadeh, K. (2014) Reproductive Characteristics and Thyroidal Function in Relation with Season in Khuzestan Buffalo (Bubalus bubalis ) Bulls. Veterinary Research Forum, 5, 201-205.

[21] Kumar, M., Kaur, H., et al. (2015) Dietary Inorganic Chromium in Summer-Exposed Buffalo Calves (Bubalus bubalis): Effects on Biomarkers of Heat Stress, Immune Status, and Endocrine Variables. Biological Trace Element Research, 167, 18-27. https://doi.org/10.1007/s12011-015-0272-0

[22] Todini, L., Malfatti, A., Valbonesi, A., Trabalza-Marinucci, M. and Debenedetti, A. (2007) Plasma Total T3 and T4 Concentrations in Goats at Different Physiological Stages, as Affected by the Energy Intake. Small Ruminant Research, 68, 285-290. https://doi.org/10.1016/j.smallrumres.2005.11.018

[23] Lima, A.S., Claudia, M., Sucupira, A. and Ortolani, E.L. (2011) Bovinos submetidos a dietas deficientes em energia por longo período: desempenho animal e sua relação com os teores de T3 e IGF-1. Brasilian Journal of Veterinary Research and Animal Science, 48, 19-26. https://doi.org/10.11606/S1413-95962011000100003

[24] Reist, M., Erdin, D., Von Euw, D., Tschuemperlin, K., Leuenberger, H., Delavaud, C., Chilliard, Y., Hammon, H.M., Kuenzi, N. and Blum, J.W. (2003) Concentrate Feeding Strategy in Lactating Dairy Cows: Metabolic and Endocrine Changes with Emphasis on Leptin. Journal of Dairy Science, 86, 1690-1706. https://doi.org/10.3168/jds.S0022-0302(03)73755-2 